\title{
PROBLEMS CAUSED BY SMALL PIG FARM ODOR AROUND THE WESTERN SONGKHLA LAKE BASIN
}

\author{
Papontee Teeraphan \\ Faculty of Law, Thaksin University, Phattalung, Thailand \\ Email : papontee_god@ hotmail.com
}

\begin{abstract}
Pollution is currently a significant issue arising awareness throughout the world. In Thailand, pollution can often be seen in any part of the country. Air pollution is pointed as an urgent problem. This pollution has not damaged only to human health and lives, it has destroyed environment, and possibly leading to violence. In Phattalung, air pollution is affecting to the residents' lives. Especially, when the residents who are mostly agriculturists have not managed the waste resulted from the farm. In Phattalung, at the moment, there are many pig farms, big and small. Some of them are only for consuming for a family, some, however, are being consumed for the business which pigs will be later purchased by big business companies. Therefore, concerning pollution, the researcher and the fund giver were keen to focus on the points of the air pollution of the small pig farms. This is because it has been said that those farms have not been aware on the pollution issue caused by the farms. Farm odor is very interesting which can probably lead to following problems. The researcher also hopes that this research can be used as a source of information by the government offices in order to be made even as a policy or a proper legal measurement. As the results, the study shows that, first, more than half of the samples had smelled the farm odor located nearby their communities, though it had not caused many offenses. Second, the majority had decided not to act or response in order to solve the odor problem, but some of them had informed the officers. The proper solutions in reducing offenses caused by pig farm odor were negotiation and mediation. Last, the majority does not perceive about the process under the Public Health Act B.E. 2535.
\end{abstract}

Keywords : Pig farm; Odor; Songkhla lake

\section{Introduction}

Phattalung is a province located in the Southern part of Thailand. Its length is about 78 kilometers and about 53 in width. Phattalung's area approximately is 3,424 square kilometers connected to Nakhon $\mathrm{Si}$

Thammarat, Songkhla, Satun and Trang. Phattalung is well known as an agricultural province, as well as it has a big basin called "Songkhla lake basin" where has been admired as a heart of 
farmers. Songkhla lake basin is one of the greatest natural resources for agriculture, fishery and tourism in the Southern Thailand.

Phattalung has approximately 520,419 residents. This number is divided into 254,372 males and 266,047 females. (Royal Thai Government Gazette., B.E.2558. No.132.) Most of the residents have lived within their own family which mostly are agriculturists, such as rice farmers, rubber farmers and fruit gardeners, fishermen. The residents live humbly and closely to one another as simply seen in a folk society.

However, recently, it can often be seen that Phattalung has been facing with pollutions. Water pollution, air pollution and waste are the particular examples. It is more unfortunate that the management coping with those problems is ineffective. So as the consideration, the air pollution caused by small pig farms is the interesting issue and has effects to the residents' lives. This accords with the fact that in Phattalung, especially around Songkhla lake basin, there are many residents who have their own pig farms. Since last few years, the amount of the number of pig farms has increased rapidly, and at the moment, they do both individually and contractly with business entitles in the areas (Suwes Keaw-on, 2006). Even though it is sometimes found that some of the pig farms have behaved rightly, to save the environment and society, under the standard of the laws, some, especially the small farms located around Songkhla lake basin, has not exercised and met the standard. This has led Phattalung and Songkhla lake basin in the following troubles, such as pollution and argument in the communities.

(Danuporn

Keereekijkajohn, 2007). This significant issue has arisen awareness of local government offices and the residents afterward.

This study was to research the existence of the problems caused by small pig farm odor in Phattalung, around the Western Songkhla lake basin and it is to analyze the appropriate solutions for the residents 
and their communities. This study had 3 core objectives as follows;

1. It aimed to survey and analyze the existence of odor from small pig farms in 10 subdistricts around the Western Songkhla lake basin, Phattalung.

2. It aimed to survey and analyze the existence of offense caused by small pig farm odor and its types in 10 subdistricts around the Western Songkhla lake basin, Phattalung.

3. It aimed to survey and analyze the solution and its process caused by small pig farm odor in 10 subdistricts around the Western Songkhla lake basin, Phattalung.

This study was conducted by mixed methodologies, both quantitative and qualitative methods. The information and statistics were firstly surveyed by a use of a questionnaire. It was followed by an analysis under the laws, legal perspectives and related legal documents. This study was conducted in 10 subdistricts in Phattalung located around the Western Songkhla lake basin. The 10 subdistricts were Ta Lae Noi, Pa Nang
Tung in Kuan Ka Nun district, Lam Pam in Meuang district, Jong Ta Non, Han Phor in Kao Chai Son district, Nar Pa Kor in Bang Keaw district and Aou Pa Yoon, Don Pra Doo, Kho Mark, Pha La Mee in Pak Pa Yoon district.

\section{Methodology}

This study was conducted firstly by reviewing texts, articles, thesis, research on related topics, and other related documents. It was then done by the field survey using the questionnaires. These questionnaires were handed to 20 Thaksin University law students, so that the samples were requested to finish and send them back to the law students afterward. The researcher afterward collected and analyzed them with the statistic program, after having the statistic results, the process was followed by the analysis with laws and legal perspectives.

The population of this study was the residents who live within 500 meters from 32 small pig farms located in 10 subdistricts around the Western 
Songkhla lake basin. Samples size was picked as 10 per 1 small pig farm. As a result, the samples consisted of 320 residents which were family representatives. The instrument of this study was the questionnaire which consisted of openended and closeended questions (multiple-choice). Samples were asked to choose one answer or more than one for each question in those parts of the questionnaire. The content of the questionnaire is divided into 4 parts as follow : Part 1 Personal information such as gender, age, education, career, marriage status and a number of family member; Part 2 The existence of the odor from small pig farms, the existence of offense caused by small pig farm odor and its types ; Part 3 The solution for the offense and its process ; Part 4 Other problems and suggestions related to the problems caused by small pig farm.

The instrument was made by the following process: The researcher had reviewed texts, articles, thesis, research on the topic and other related documents; The researcher made the scope of the content regarding to the objectives; The researcher created the questionnaire; The questionnaire was given to the experts and the peer-review committee on the Project of the Survey to Health and Quality of Life of Residents around the Western Songkhla Lake Basin for advice ; After editing the content, the questionnaires were printed for 320 papers ; A questionnaire was sent to the Thaksin University ethics committee in human research to review on the ethical issues.

Data collection process in this study was exercised as follow: Thaksin University issued official letters to the chief executives of the subdistrict administrative organizations and the mayors for the permission of entrance; The 320 questionnaires were given to the law students in order to be used with the samples and it must be returned to the researcher by the end of the surveying day ; All returned questionnaires were examined for their completeness and accuracy prior to data collection.

The study was used the basic statistics which were percentage, mean, standard deviation and frequency. The small 
pig farms in the studied areas caused the unpleasant odor to the residents. This would a little cause some offenses in the areas. The majority considered that the solution should exercise by negotiation between the farm owners and the affected residents.

Small pig farm means a farm consisting of pigs, in any kinds, which the amount of pig weight is during 6 to 60 livestock units in total. The amount of weight can be calculated as follows; A boar or a sow's weight is 170 kilograms, a finishing pig's weight is 60 kilograms and a piglet's weight is 12 kilograms; A 500-kilograms of pig weight in a farm is equal to 1 livestock unit. (Pollution Control Department, 2012)

\begin{tabular}{|c|c|c|}
\hline Information & Frequency & Percent \\
\hline \multicolumn{3}{|l|}{ Gender } \\
\hline - Male & 152 & 47.5 \\
\hline - Female & 168 & 52.5 \\
\hline Total & 320 & 100.0 \\
\hline \multicolumn{3}{|l|}{ Education } \\
\hline - Never study & 17 & 5.3 \\
\hline - Primary school & 206 & 64.4 \\
\hline \multirow{2}{*}{$\begin{array}{ll}\text { - } & \text { Secondary } \\
\text { school }\end{array}$} & 48 & 15.0 \\
\hline & 36 & 11.3 \\
\hline - High school & 13 & 4.0 \\
\hline - Bachelor degree & 0 & 0 \\
\hline - Master degree & 0 & 0 \\
\hline $\begin{array}{l}\text { Doctoral degree } \\
\text { Total }\end{array}$ & 320 & 100.0 \\
\hline \multicolumn{3}{|l|}{ Career } \\
\hline \multirow{2}{*}{$\begin{array}{l}\text { - Government } \\
\text { officer }\end{array}$} & 9 & 2.8 \\
\hline & 65 & 20.3 \\
\hline \multirow{3}{*}{$\begin{array}{l}\text { - Grocery owner } \\
\text { or other } \\
\text { business owner }\end{array}$} & 24 & 7.5 \\
\hline & 144 & 45.0 \\
\hline & 8 & 2.5 \\
\hline - Labor/Employee & 49 & 15.3 \\
\hline - Agriculturalist & 21 & 6.6 \\
\hline - Student & (11) & (3.6) \\
\hline - Jobless & (9) & (3.0) \\
\hline \multirow{2}{*}{\multicolumn{3}{|c|}{$\begin{array}{c}\text { - Other jobs } \\
\text { Fisherman }\end{array}$}} \\
\hline & & \\
\hline \multicolumn{3}{|l|}{ Housewife } \\
\hline \multicolumn{3}{|l|}{ Total } \\
\hline \multicolumn{3}{|l|}{ Marriage Status } \\
\hline - Single & 45 & 14.1 \\
\hline \multirow{2}{*}{$\begin{array}{l}\text { Married with } \\
\text { legal certificate }\end{array}$} & 227 & 70.9 \\
\hline & 35 & 10.9 \\
\hline - Married without & 4 & 1.3 \\
\hline legal certificate & 9 & 2.8 \\
\hline - divorce & 320 & 100.0 \\
\hline - widow & & \\
\hline Total & & \\
\hline
\end{tabular}

Table 2. The average of age and number of family member of the samples

\begin{tabular}{crr}
\hline Information & Mean & $\begin{array}{l}\text { Standard } \\
\text { Deviation }\end{array}$ \\
\hline Age & 52.5 & 15.56
\end{tabular}


UBELAJ, Volume 1 Number 1, April 2017 | 6

Family

member

According to table 1 and 2, among the 320 residents, the $47.5 \%$ were male and the $52.5 \%$ were female. They were in average of age at 52.5 years old and the standard deviation was 15.56. The average of family member was 3.8, while and the standard deviation was 1.5. The $64.4 \%$ graduated from primary school, followed by secondary school with $15 \%$, and high school with $11.3 \%$. The $45 \%$ was agriculturalist, whereas grocery owner or other business owner was followed with $20.3 \%$, and some of them, $15.3 \%$, were unemployed. Most of the samples, $70.9 \%$, got legally married, while $14.1 \%$ was single.

Part 2 The existence of the odor from small pig farms, the existence of offense caused by small pig farm odor and its types.

Table 3 The existence of the odor from small pig farms

Information
Frequency Percent

\begin{tabular}{|c|c|c|}
\hline $\begin{array}{l}\text { The existence of the } \\
\text { odor from small pig }\end{array}$ & 178 & 55.5 \\
\hline farms & 142 & 44.5 \\
\hline $\begin{array}{ll}\text { - } & \text { existing } \\
\text { - } & \text { not existing } \\
& \text { Total }\end{array}$ & 320 & 100.0 \\
\hline
\end{tabular}

According to table 3, the study has shown that the odor caused by the small pig farms existed as $55 \%$, the $44.5 \%$, however, did not smell the odor. Table 4 The existence of offense caused by small pig farm odor and its types.

Information Frequency Percent

\section{The existence of}

offense caused by

small pig farm odor 25

- existing

- not existing

Total

The types of the

offense*

$3 \quad 12.0$

- insult

- threat

0

0

- battery

- battery resulted to disability

- murder

*The samples could pick more than one category.

According to table 4, within $55 \%$ of the samples mentioned in table 3 above, the study has disclosed that some offenses occurred afterward as 
$14.2 \%$ which the charges of the offense were insult and threat. However, the $85.8 \%$ of the samples thought that there was no offense in the communities. The further reason was given that this is because the residents who live in the communities did not want to have uncomfortable feeling and situation in the communities. Most of them were residents who had known each other quite well. Some, moreover, were relatives.

Part 3 The solution for the odor, the offense and its process. Table 5 The solution for the odor

\begin{tabular}{|c|c|c|}
\hline Solution* & $\begin{array}{l}\text { Freque } \\
\text { ncy }\end{array}$ & Percent \\
\hline $\begin{array}{ll}\text { - } & \text { Informing } \\
\text { police } \\
\text { - } & \text { Informing } \\
\text { village } \\
\text { headman or } \\
\text { subdistrict } \\
\text { headman } \\
\text { - } \text { Informing } \\
\text { municipality or } \\
\text { subdistrict } \\
\text { administrative } \\
\text { organization } \\
\text { - Informing } \\
\text { district } \\
\text { administration } \\
\text { Informing } \\
\text { directly to the } \\
\text { owner } \\
\text { Do nothing }\end{array}$ & $\begin{array}{c}1 \\
2 \\
196\end{array}$ & $\begin{array}{c}0.3 \\
0.6 \\
60.4\end{array}$ \\
\hline
\end{tabular}

*The samples could pick more than one category.

According to table 5, the $60.4 \%$ of the samples had never exercised anything to solve the problem, whereas the $24.6 \%$ had informed the village headmen or the subdistrict headmen. The $13.5 \%$ had decided to inform the municipalities or subdistrict administrative organizations which held the accountability in the studied areas. The rest of them chose to inform the police, the farm owners and the district administrations.

Table 6 The opinion for the solution of a use of offense

\begin{tabular}{lcc}
\hline \multicolumn{1}{c}{ Opinion* } & $\begin{array}{l}\text { Freque } \\
\text { ncy }\end{array}$ & Percent \\
\hline - Using law & 67 & 20.9 \\
enforcement & 214 & 66.9 \\
strictly & 26 & 8.1 \\
- Using & $(22)$ & $(6.9)$ \\
negotiation & $(1)$ & $(0.3)$ \\
between odor & $(2)$ & $(0.6)$ \\
$\quad \begin{array}{l}\text { maker and } \\
\text { residents }\end{array}$ & $(1)$ & $(0.3)$ \\
- Using mediation & 9 & 2.9 \\
$\quad \begin{array}{l}\text { by Village } \\
\text { headman }\end{array}$ & 4 & 1.2 \\
Subdistrict headman & & \\
Chief Executive of \\
the subdistrict
\end{tabular}


organization /

Mayor Not given

- No opinion

- No solution

*The samples could pick more than one category.

According to table 6, the $66.9 \%$ considered that the negotiation between the odor makers and the residents should be used as a solution for an offense. It is then that $20.9 \%$ of the samples agreed that the solution should use a strict law enforcement. The $8.1 \%$ of the samples thought that the offense should be solved by the mediators, such as the village headman, the subdistrict headman and the chief executive of the subdistrict administrative organization or the mayor. The $2.9 \%$ and $1.2 \%$, however, informed for no opinion and no solution.

Table 7 The opinion to the law dealt with pig farm odor

\begin{tabular}{lcl}
\hline \multicolumn{1}{c}{ Opinion } & Frequency & Percent \\
\hline - Law is complex in & 17 & 5.3 \\
use & 66 & 20.6 \\
- Law is not complex & 237 & 74.1 \\
in use & & \\
- No opinion & & \\
because no & & \\
understanding to & & \\
the law & & \\
\hline
\end{tabular}

According to table 7 , the result has shown that the $74.1 \%$ of the samples had no understanding of the laws which will be used and to deal with the pig farm odor, whereas the $20.6 \%$ had a consideration that the law enforced to the pig farm odor was not complex in use.

Part 4 Other problems and suggestions related to the problems caused by a small pig farm.

Table 8 Other problems caused by a small pig farm.

Number Problem Frequency

\begin{tabular}{lll}
\hline 1. & Ignorance of the & 4 \\
government office & 1 \\
& Personal lawsuit
\end{tabular}

According to table 8 , the other following problems were the ignorance of the government office and the personal lawsuit by the resident.

Table 9 Other suggestion related to the problems caused by a small pig farm.

\begin{tabular}{clc}
\hline Number & Suggestion & Frequency \\
\hline 1 & $\begin{array}{l}\text { Observation of } \\
\text { village civil society }\end{array}$ & 2 \\
\hline
\end{tabular}


According to table 9, the result reveals that the observation of village civil society may be used as a means to solve the problems. The further information was given that before having a pig farm, there should be a meeting of village civil society in a community. This is an ideal which will allow residents to have discussions to the pig farm owner, as well as this may reduce the possibility of having argument or even offense in the future.

\section{Conclusion}

More than half of the samples accepted that there was pig farm odor existence in the communities though the odor would not make many offenses. Most of the samples had never exercised anything in order to solve the odor problem. This is due to the domestic relation in the communities. Some, however, informed the village headmen or the subdistrict headmen. More interestingly, a few decided to inform the municipalities or the subdistrict administrative organizations which held the accountability in the studied areas.

For the solution of offense caused by small pig farm odor, in their opinions, strict law enforcement was not the first option to cope with this problem. However, most of the samples suggested that a use of negotiation would be more useful and appropriate. A use of mediation was opted in the third place which the role of the mediator, such as a village headman, a subdistrict headman and a chief executive of a subdistrict administrative organization or a mayor, would be very significant.

The majority did not perceive and have an understanding of the law, the Public Health Act B.E. 2535.

In this study, the researcher has demonstrated the interesting points as follow: The odor caused by the small pig farms in the studied areas is a nuisance under the Public Health Act B.E. 2535 . The section 25 of the act is mentioned that "In a case of nuisance affecting to residents who live nearby or to any person who is facing to, these are nuisance 1) water resource, sanitary 
sewer, bathing-place, lavatory, muck keeping place or other places which is located in an inappropriate place, dirty or accumulated caused unpleasant odor, poisoning dust, the place for breeding of disease vectors or damage to health ; 2) animal farming in any place with any means or with an improper amount of animal which causes health damage or health risk ; 3) building used for human or animal living or used as a factory which there is no ventilation, drainage, waste disposal or poison control and causes damage to health or health risk ; 4) any action which causes odor, light, radiation, sound, heat, poisoning thing, trembling, dust or any thing which will lead heath risk or result damage to health ; 5) any causes specified and announced in the Royal Thai Government Gazette."

In practice, even though, the odor would not lead many offenses in the communities because of the good relation between the farm owners and the affected residents, furthermore, some of them were relatives of each other or were well known to one another in the communities. The affected residents would not make an uncomfortable situation, if there is an offense taking place, all of them were petty offenses under the Penal Code as follow (Netayasupha, Pisitpit and Watcharavutthichai, 2010); Section 393, insult, whoever insults any person in his or her presence or by publication shall be liable to imprisonment for not exceeding one month or fine of not exceeding one thousand Baht, or both. Section 392, threat, whoever puts any person to fear or fright by threat shall be liable to imprisonment for not exceeding one month or fine of not exceeding one thousand Baht, or both. These criminal charges can be operated beyond the criminal proceeding starting only by complaining, by injured person, to police, so without that, there will be no criminal proceeding and no offender punished. For the further information, such as the number of the cases complained by the injured person and has been run in the criminal justice proceeding, is still needed to research. This will help as a management tools in criminal justice system. 2. The operation to solve the odor was 
demonstrated by ignorance, followed by informing to the village headmen or the subdistrict headmen. This accords with the law named "the Local Government Act B.E. 2457" (Local Government Act B.E. 2457, amended in B.E. 2551)

In the context of the law, section 27 (4) states that a village headman operates his or her duty by helping the district chief officer and being a leader in a village, as well as having these power and obligations; (4) receiving problems and reflex the needs of residents to government offices, state agencies, local government offices or other related organizations for a solution or help.

And section 34 bis. states that besides the specific duties, a subdistrict headman shall also have the duties as same as a village headman. According to the law above, this means that when a village headman or a subdistrict headman receives the odor complaint from their residents, they quickly have to inform those problems to a person who is accountable under the Public Health Act B.E. 2535 which are a chief executive of a subdistrict administrative organization or a mayor depending on the types of the subdistrict.

Moreover, regarding the Public Health Act B.E. 2535, the section 26 to the section 28 gives the power and obligations to those accountable officers, such as the power to warn a person who makes the odor problem, the power to force a person who makes the odor problem for solving the odor problem in the proper time, the power to solve the odor problem by themselves and acquire the expense from the problem makers (Public Health Act B.E. 2535, amended in B.E. 2550).

However, concerning to table 5, it can be seen that informing to a chief executive of the subdistrict administrative organization or a mayor was not picked in the first place by the samples, though under the law, this problem will be under the accountability of those local government officers. On the other hand, informing to any person else can delay for a solution as well as the ones who 
are informed will have no direct power to solve the problem.

Interestingly, strict law enforcement is not the best solution for any offenses caused by small pig farm odor. Negotiation between the farm owner and the affected residents is the most appropriate solution. However, if the negotiation is used to solve offenses, the effectiveness should importantly be considered because it may be difficult to solve the problem by only the problem maker and the affected people. Alternative dispute resolution is an option for those who have argument or offenses to each other. This accords with the result from the study above showing that mediation is the option for the problem maker and the affected people as well. A village headman, a subdistrict headman and a chief executive of the subdistrict administrative organization or a mayor may be a mediator. However, other further information, such as the role of the mediator, their readiness and the appropriate legal model for mediation is still needed to find out. This is to ensure that this means operates effectively.

The awareness of the government whether central or local on the understanding of people on the Public Health Act B.E. 2535 is a significant issue. When the residents know nothing about their rights and the process to cope with this problem under the law, there can be nothing done legally. This leads the less capacity of the residents when the odor problem occurs.

The study is suggested to use as follows; 1. When the argument or offense occurs in the community, the preference in coping with those problems is Alternative Dispute Resolution (ADR). This resolution is divided, only related, into negotiation, mediation. Those means should be used effectively. Particularly, for the mediation, the mediators, such as a village headman, a subdistrict headman and a chief executive of the subdistrict administrative organization or a mayor, will be having a very important role. Therefore, they should have awareness, legal and social knowledge before being a mediator ; 2 . The government 
offices which are accountable, such as the municipality or the subdistrict administrative organization, should have collaboration with the village headman or the subdistrict headman. This can gain effectiveness to solve the problems ; 3. The residents should, at least, be given the knowledge and understand the process to cope with the problems under the Public Health Act B.E. 2535. The suggestion for a further research is about a role of a mediator and their readiness, an appropriate legal model for the disputes in the community.

\section{Acknowledgements}

This research was funded by the Institute of Research and Development for Health of Southern, Thailand and the Thai Health Promotion Foundation. The researcher would like to express my sincere gratitude to both funding supporters, as well as to Thaksin University where the researcher have been working.

\section{References}

Keaw-on, S., (2006). A Study of State and Problems of Swine Farming for Business in Lerngnokta, Kudchum, and Thaichareon Districts, Yasothon Province. Ubon Ratchathani Rajabhat University, Ubon Ratchathani.

Keereekijkajohn, D., (2007). Control and Management of Waste Water and Odor from Pig Farm. Thammasat University, Bangkok.

Local Government Act B.E. 2457. (amended in B.E. 2551)

Netayasupha, A., Pisitpit, P., Watcharavutthichai, B., (2010). The Penal Code, Winyuchon Press, Bangkok.

Pollution Control Department, (2012) A guidance to work in accordance with legal regulations. Bangkok.

Public Health Act B.E. 2535. (amended in B.E. 2550)

Royal Thai Government Gazette., B.E.2558. No.132, p. 11-14. 